\title{
Cabinets, Committees, and Careers: The Causal Effect of Committee Service
}

\author{
Alexandra Cirone, Cornell University \\ Brenda Van Coppenolle, Leiden University
}

What is the value of committee service to an individual legislator? Self-selection and party control of appointments typically obscure this relationship. We estimate the causal effect of committee service on legislative behavior and parliamentary careers by exploiting a natural experiment in the French Third Republic (1870-1940). Yearly lotteries divided the legislature into groups that nominated members to the budget committee, and we use the random composition of these groups as an instrument for individual appointment. We find that appointment increased legislative entrepreneurship concerning budget legislation but not other types, suggesting that committee members acquire specialized expertise. Committee service also led to ministerial appointment but not to higher office that does not require specific policy expertise, such as party or senatorial positions. Finally, we discuss alternative mechanisms, including reputation effects, political networks, and distributional targeting via pork barrel legislation.

$\mathrm{W}$ hat is the value to an individual legislator of committee service? How do committee appointments independently affect legislative behavior, and does this experience improve future parliamentary careers? Scholars have long claimed that committee membership is a distinct political asset with a number of electoral and legislative benefits (Cox and McCubbins 1993; Krehbiel 2004; Mayhew 1974). Yet even though a large body of observational research has explored this, there is no clear evidence for an independent career effect of committee service. Some studies have shown that committee assignment positively affects legislative productivity, higher office, and electoral success (e.g., Cox and Terry 2008; Grimmer and Powell 2013; Schiller 1995), while others find that it has little impact on legislative activity (Anderson, Box-Steffensmeier, and Sinclair-Chapman 2003), pork barreling (Berry and Fowler 2016), or legislator careers, particularly outside of the US context (e.g., Crisp et al. 2009; Khmelko, Wise, and Brown 2010; Olson and Norton 2007). Competing results could be explained by the fact that isolating the independent effect of committee membership on individual behavior is notoriously difficult, due to concerns with selection bias and endogeneity.
The main empirical challenge in identifying the causal effect of committee service on legislative careers is distinguishing the effects of membership from selection onto committees (Berry and Fowler 2016; Broockman and Butler 2015; Cox and McCubbins 1993; Hedlund et al. 2011; Krehbiel 1991). Committee seats are not assigned randomly. Legislators who succeed in achieving a committee post might be more senior, more skilled, or more charismatic than their peers; or legislators might be put on high profile committees precisely because they are effective. One significant threat to inference is that it may be these characteristics - not the legislative office itself - that determine future success.

Another threat to inference derives from the fact that political parties often control both committee selection and career prospects (Hedlund et al. 2011). Party leaders could potentially distribute committee assignments to incentivize party loyalty or achieve their policy goals within the committee, or assignments could be given to party members with preexisting skills or demand. If the factors behind legislators' eventual career outcomes are correlated with the rationale for partisan committee assignments, then this confounds any attempt to isolate the independent effect of legislative insti-

Alexandra Cirone (acirone@cornell.edu) is an assistant professor in the Government Department at Cornell University, Ithaca, New York, 14850. Brenda Van Coppenolle (b.k.s.van.coppenolle@fsw.leidenuniv.nl) is assistant professor in the Institute of Political Science at Leiden University, Leiden, The Netherlands, 2333 AK.

Data and supporting materials necessary to reproduce the numerical results in the paper are available in the JOP Dataverse (https://dataverse.harvard.edu /dataverse/jop). An online appendix with supplementary material is available at http://dx.doi.org/10.1086/697252.

The Journal of Politics, volume 80, number 3. Published online May 14, 2018. http://dx.doi.org/10.1086/697252

(C) 2018 by the Southern Political Science Association. All rights reserved. 0022-3816/2018/8003-0015\$10.00 
tutions. Related to this, there could be several mechanisms driving the effect of committee service on careers, which are often difficult to measure and then test with empirical data (Krehbiel 2004). To resolve such issues, a small number of studies (Broockman and Butler 2015; Grimmer and Powell 2013; Kellerman and Shepsle 2009) have exploited institutionalized randomizations to identify the individual benefits to committee service, but these are limited to the setting of the United States. As natural experiments in committee selection are rare, this makes it even more important to learn from the few cases that do exist.

We provide a study that allows us to causally identify the effects of committees on careers by exploiting a natural experiment in the early years of the French Third Republic (1870-1940). The lower house of the National Assembly, the Chambre des députés, featured an egalitarian selection process with a random element that allows us to identify the impact of committee service on careers in a new democracy. Periodically, the legislature was randomly assigned into 11 groups called bureaux, and then each group chose members to serve on the powerful budget committee. Further, the French legislature is an ideal case because the powerful budget committee was the only standing committee for this period, so our estimates are not affected by intercommittee competition or selection into different types of committees. France also lacked a formalized party system, and emerging parties were not able to confound any analysis of committee selection.

The competitiveness of a deputy's bureau serves as a unique instrument for nomination to the budget committee. We construct an instrument that is the number of budget incumbents in a deputy's bureau, excluding the deputy; this measures how likely the deputy would be to win the nomination. This instrument is strongly correlated with committee selection. These temporary bureaux served no other purpose than nomination and therefore have no other effect on legislator behavior or careers than through committee selection. We use an instrumental variable (IV) research design to estimate the career returns to committee membership for individual deputies.

Our research design allows us to empirically test a number of channels through which committee service could affect legislative behavior and careers. We are most interested in how committees help members develop specialized skills. This is a prominent argument in canonical theories of legislative organization (Gilligan and Krehbiel 1987, 1990; Krehbiel 1991), yet this literature is grounded exclusively in the study of the two-party US Congress. There are very few microlevel studies of how committee appointment affects individual behavior in either multiparty parliamentary systems or democratizing regimes (Jones, Saiegh, and Spiller 2002; Krehbiel 1991; Zubek 2015). Thus, we extend the logic behind this theory to analyze institutional features in the French parliamentary context, to test whether committee service incentivized the acquisition of expertise and whether this translated into an increased probability of obtaining higher office in a deputy's career. In addition, we empirically test a set of alternative theories to explain the effect of committee service. Serving on a high profile committee could provide a valence boost to a legislator's reputation (Epstein et al. 1997; Katz and Sala 1996), could provide a political network with which to enhance their career (Fowler 2006), or could give a legislator the ability to target benefits to constituents (Mayhew 1974; Weingast and Marshall 1988); we address each of these in turn.

Our findings suggest that the value of committee service derives from the acquisition of specialized expertise by members. We first estimate the effect of committee appointment on legislative productivity, as measured by bill sponsorship. We show that as a result of budget experience, deputies are much more likely to sponsor future budget amendments. This effect exists only for budgetary legislation, the topical focus of the committee, indicating specialized "learning on the job." Importantly, France was missing one of the key institutional incentives that drive traditional informational theories of American politics, namely restrictive rules, yet we demonstrate how the legislative structure instead provided alternative incentives for specialization. In doing so, we contribute to the growing body of comparative research on legislative organization in parliamentary settings and add behavioral implications that complement studies that look at the strategic choice to use restrictive rules in committee systems (e.g., Moffett 2012; Monroe 2008).

We then estimate the probability a budget committee member will acquire higher office in the future and find a strong and positive effect of committee service on ministerial appointment. There is no effect of budget service on other forms of career advancement, specifically career positions that do not rely heavily on specific policy expertise, such as party leadership or senatorial positions. This reinforces the idea that committees enhance careers via skill acquisition. We also explore alternative mechanisms, including network effects, reputation, and distributional theories. Yet deputies are no more likely to cosponsor legislation with their former committee members, a practice that plausibly measures network-based effects, and committee service has no reputational effect on reelection or choice to stand for office. Finally, we find that those who served on the budget committee are no more likely to sponsor future credit bills, a particularly effective way for Third Republic deputies to target pork to their constituency. 
The contribution of our paper is threefold. First, we leverage a natural experiment to provide causal evidence on the effect of committee experience on both legislative behavior and political careers. In doing so, we contribute to a new literature utilizing institutional randomizations to study the link between legislative rules and politician behavior (Broockman and Butler 2015; Grimmer and Powell 2013; Kellermann and Shepsle 2009). Second, by studying France, we provide empirical evidence of how implications deriving from informational theories of legislative organization could extend to multiparty, parliamentary settings outside the United States.

Finally, while we exploit a seemingly innovative institution, in the form of randomized bureaux, this procedure is not rare. Lottery-based procedures in committee systems were common in nineteenth-century continental Europe (Cirone and Van Coppenolle 2018), and random committee assignment was used for corruption trials in Victorian Britain (Eggers and Spirling 2014). In contemporary parliamentary settings, committee seniority rankings and assignment orders are partially determined by lottery in the US Congress (Kellerman and Shepsle 2009) and the German Bundestag (Buchstein and Hein 2009), and lotteries are used in other ways, such as to choose the ordering of private bills and questions considered in the United Kingdom and India (Bowler 2010), Canada (Loewen et al. 2014), and New Zealand (Williams and Indridason 2014). More importantly, partial or full randomization of committee selection has been recently suggested for the United Kingdom, France, and the European Union (Barnet and Carty 2008; Buchstein and Hein 2009, and in Ségolène Royal's 2007 presidential platform), demonstrating the importance of the further study of such procedures.

\section{BUDGET COMMITTEE OF THE THIRD REPUBLIC}

The French Third Republic was the system of government in France from 1870 to 1940 . Our study focuses on the most salient and powerful committee - the budget committee. Established at the start of the regime, it was the only permanent standing committee in the Chamber until 1902 and was annually and consistently appointed throughout the entire regime (Usher 1906). The budget committee comprised 33 members, tasked with reviewing the draft annual budget presented by the finance minister each October. Unlike the more structured finance committee of the later Republics (Huber 1996), this group was effectively an independent council outside the government, with extensive investigative and legislative powers. ${ }^{1}$ Members had the ability to essentially remake the government's budget (Gooch 1928), and neither the president nor

1. At this time, the assembly had yet to establish a professional and institutionalized support staff. the cabinet could induce the committee to finish more quickly. When compared to the short life of most ministries, it is easy to see why committees were "effectively masters of the executive" (Chapman 1962).

Parties typically play a large role in the allocation of committee posts, yet-like many new democracies - the French Third Republic began with stable legislative institutions but a fledgling and weak party system. A bicameral parliament was established in 1875, and France was divided into over 600 voting districts that under universal manhood suffrage each elected one deputy to the lower house of the National Assembly. Parties, or rather loose parliamentary groupings, only existed within the Chamber. Ideologically, the multiparty Chamber was dominated by the center-left Radical party, flanked by conservatives and center-right progressives on one side and radical socialists and socialists on the other. ${ }^{2}$ These parliamentary factions had no legislative power, and party weakness shielded committees from being instruments of partisan control (Mayeur 1984). The absence of a formalized party system helps us to analyze the effect of committee service without confounding partisan factors.

For the majority of the regime, the selection of committee assignments was neither controlled by political parties nor governed by procedures such as seniority or tenure. Instead, budget committee members were selected by a lottery-based procedure. Yearly lotteries divided the entire legislature in groups called bureaux, ${ }^{3}$ which then nominated members to the budget committee. This system of bureaux was initially established to prevent any one political faction from capturing control of this powerful institution. It then existed for over 30 years, even though it could produce suboptimal outcomes. For example, the minority in the Chamber could hold the majority in the greater number of bureaux and thus create an unrepresentative committee. Similarly, if all deputies with one particular skill were randomly assigned to a few bureaux, the committee could suffer from a lack of expertise (Usher 1906). Only in 1910, when parties had consolidated, was the committee system reformed to give parliamentary groups control over committee assignments. ${ }^{4}$

2. Groups provided some basis for partisan coordination; however, the most numerous party groups such as the Radicals were also the most heterogeneous, and deputies could hold multiple affiliations in groups as late as 1902 .

3. We use the French terminology, using bureaux for plural and bureau for singular. This system was initially used to assign committees in the National Constituent Assembly during the French Revolution and was adopted for both efficiency and to counteract factional behavior.

4. Instead of election via the bureaux, committee positions were allocated proportionally to political parties, who then filled these slots using party-controlled lists. 
Given this institutional structure, the powerful budget committee had the potential to influence careers. We turn next to discuss the specific theoretical channels through which committee service could affect legislative behavior.

\section{CHANNELS THROUGH WHICH COMMITTEES CAN AFFECT CAREERS}

As a result of this natural experiment in the French Third Republic, we can explore a set of causal mechanisms driving the individual benefits to committee service. We take as our starting point an important question emerging from the existing American politics literature, which asks to what extent committees teach their members specialized skills. We explore this question by turning to informational theories of legislative organization. Our focus is not on institutional choice, as the legislative organization of France was fixed throughout the period of our study. Yet these theories explicitly map committee structure to a set of behavioral incentives, and consequently can provide behavioral predictions for how committees affect careers. In addition, we present a number of alternative mechanisms that could instead explain the career benefits of committee experience, including reputation effects, political networks, and distributive politics.

\section{Specialization and skill acquisition}

Prominent informational theories of legislative organization in American politics argue that the benefits of committees stem from their ability to encourage legislators to acquire specialized knowledge. Yet since information acquisition is costly, legislatures must provide committee members with incentives to develop such expertise. Gilligan and Krehbiel (1987, 1989, 1990; Krehbiel 1991) use a legislative signaling model to demonstrate that closed rules (or the inability of the chamber floor to amend) protect a committee's legislative proposal to the floor, thereby providing the incentives necessary for its members to ex ante invest in expertise. A number of studies have expanded this seminal model, ${ }^{5}$ but all conclude that for legislators to specialize, committees must be desired, durable, and most notably, feature a set of restrictive amendment rules.

However, the powerful budget committee in the Third Republic was missing these crucial institutional characteristics. The French budget committee, as detailed by Cox (2016),

5. New studies have added resources to defray committee costs (Gilligan and Krehbiel 1990), overlapping generations (Diermeier 1995), or ex ante rewards to service (Baron 2000).

6. Cox (2016) is concerned with explaining fiscal and budgetary discipline in the United Kingdom and contrasts the British system after the Glorious Revolution in which the ministry has sole budgetary proposal instead resembles a context of noncooperative, majoritarian bargaining under open rule, reflected in a canonical distributive model by Baron and Ferejohn (1989). ${ }^{7}$ The assembly allowed any deputy to propose amendments to the budget, which resulted in oversized budgets that often took more than a year to pass (Besson 1901; Cox 2016). Yearly selection via the bureaux ensured frequent committee turnover, and there were neither partisan assignments nor systems of seniority to incentivize information acquisition. Yet in this "legislative state of nature" we still find evidence for the acquisition of expertise.

We argue that while legislative institutions need to provide incentives for learning on the job, these incentives are not limited to restrictive rules in parliamentary regimes. In fact, Strom (1998) notes that both proposal power and restrictive amendment rules that are key to the case of the American Congress vary widely across the parliamentary committees of Europe. Thus we add to a growing literature identifying incentives for committee specialization outside of the US context. For example, Kellerman (2014) shows that executive oversight, in the absence of legislative authority, is enough to induce committee members to specialize in the United Kingdom; Bowler and Farrell (1995) surprisingly find specialization in the supranational European Union; and Jones et al. (2002) show how multiparty concerns and career tenure specific to Argentina run counter to traditional theories concerning investment in legislative committees.

We argue that the French institutional context provided alternative incentives for committee members to acquire specialized expertise. First, the system of yearly selection ensured turnover in budget committee membership; depending on the competitiveness of his bureau, an ambitious legislator could find himself on the budget committee one year and returned to the assembly floor the next. Once on the floor, the deputy's only chance to influence the budget would be through budgetary amendments, a process in which a deputy would clearly benefit from prior experience and specialized skills extracted during committee service. Similarly, the committee majority also knows that there are no restrictive rules protecting its proposal from moderation (Monroe and Robinson 2008); it must instead preemptively preserve its position by proposing a well-crafted bill that can withstand amendment, which also requires extensive expertise. Counter to existing theories, we

power to the open rule used in the French Third Republic to explain their relative fiscal indiscipline.

7. Under open rules, a committee is tasked with allocating a pie and is given agenda-setting power in its ability to propose a division first. The legislature is allowed to freely amend this proposal, however, and as a result the benefits are distributed more evenly across the Chamber, and the passage of the bill may face delay. It is worth noting that the BaronFerejohn model is agnostic on information acquisition. 
argue that committee turnover combined with future individual amendment rights encourages investment in budgetspecific skills.

Second, budget committee members were given additional duties and powers that could provide individual returns to developing expertise (Baron 2000). Members could conduct financial audits, negotiate with various parliamentary factions on budgetary matters, and present detailed recommendation reports to the entire chamber before discussion on any budgetary matters could begin (Lowell 1902). Finally, even though the budget could be amended, the budget committee still had a large first mover advantage in presenting the extensive budget document to the floor, and at the time this was one of the most significant agenda powers in the assembly. All gave explicit incentives to specialize, in addition to any natural learning on the job that could occur.

Based on these arguments, we would expect that committee members would be more likely to develop a set of specialized skills. More specifically, here we focus on entrepreneurial activity, one of the key functions of elected representatives. This type of activity is typically measured by bill sponsorship (Schiller 1995; Wawro 2000) and is one of the best known measures of individual effort and productivity in a legislature (Anderson et al. 2003; Cox and Terry 2008). In the Third Republic, bill sponsorship guaranteed a deputy invaluable speaking time on the legislative floor, regardless of the bill's outcome. Therefore French deputies had every incentive to draft significant bills to achieve their legislative and constituency goals. To measure specialization, we analyze the topic of the legislation sponsored, which enables us to identify bills directly related to the expertise of budget committee service.

\section{Committees and higher office}

In the case of established democracies, it has been frequently argued that a key way to ensure a long-lasting political career is to obtain a seat on an influential committee (Fenno 1978; Schlesinger 1966). In particular, we argue that the benefits of committee specialization should be most valuable in obtaining positions that value legislative expertise. Wawro (2000) and Padro i Miquel and Snyder (2006) found that "legislative entrepreneurs" who engage in drafting, introducing, or promoting legislation are more likely to see success in both promotion and reelection. If committees help train their members to be policy entrepreneurs, then we should see the returns to such experience reflected in their career trajectory.

In the French Third Republic, it has been argued that the committee system offered the opportunity to both rise to higher office and ensure reelection (Chapman 1962; Garner 1914; Gooch 1928). Gambetta, in particular, was known for pushing his career agenda while president of the budget committee from 1877 to 1881 (Zeldin 1993). In the absence of disciplined parties, committees were important in early promotion. "If a young deputy can induce his bureau to nominate him [to a committee], he starts on his political career with chances similar to those enjoyed by an engineer in his profession who has passed out of the Ecole Polytechnique with a high number" (Bodley 1898, 213). We empirically test this argument by estimating the probability that members of the budget committee are more likely to ascend to higher office in the future. We examine the positions most important for career success in the nineteenth century - a senator, a parliamentary group leader, and a cabinet minister.

Two high profile posts on the potential career paths of deputies at the time were a party leadership position in the chamber, and election to the senate. The only consistent form of partisan organization in this era was the parliamentary governing committees. Each faction in the Chamber was loosely headed by a yearly committee consisting of three to six members. ${ }^{8}$ Even though parties were weak, serving as a party representative was highly desirable, for it gave deputies name recognition, both inside and outside the legislature. Meanwhile the senate served as the upper house of the French parliament, consisting of 300 members, of which 225 were indirectly elected by the municipal councils of the departments. For an ambitious deputy, a position in the senate was desirable and a more stable career path; for its members served nine-year terms instead of five. We examine the effect of committee service on both partisan and senatorial higher office.

The most prominent position, however, was that of parliamentary minister. Here we include all classes of governmental ministers, including senior and junior ministers in the cabinet, as well as undersecretaries. In terms of selection, weak parties provided no clear role in government formation and there was frequent government turnover. Cabinets lasted on average eight months, yet ministerial selection valued prior experience - as many as half of the ministers would stay on from one government to the next. Politicians who had not held a ministerial post were judged negatively by constituents (Garner 1914), which incentivized the frequent toppling of ministries.9 This explains why, in the Third Republic, "the

8. Depending on the group, this included some combination of a founder, president, vice president, secretary, rapporteur, or questeur. Leaders were mentioned in the national paper, e.g., Le Matin, and listed in the public parliamentary record.

9. Yet unlike the Fourth and Fifth Republics (Huber and MartinezGallardo 2004; Kam and Indridason 2009), this constant instability was strategic: unrestricted amendment rules enabled rival parliamentary fac- 
general reporter of the budget is almost certainly a future minister" (Dogan 1967, 12).

\section{Alternative explanations: Reputation, networks, targeting}

There are other ways in which committee service could positively affect a politician's career trajectory, in addition to skill acquisition. We empirically test a number of alternative mechanisms, including reputation, network effects, and distributional targeting. First, serving on a high profile committee could improve a deputy's reputation. At the time, the budget committee was highly visible, and both its nomination and proceedings were mentioned frequently in national and local newspapers. If there are simple reputational advantages to committee selection, and members receive a boost in valence by serving, we could expect to see this reflected in the electoral arena (Epstein et al. 1997; Katz and Sala 1996; Mayhew 1974). We examine both whether budget experience increased a deputy's probability of running for office the next term and (conditional on running) whether it improved reelection chances.

Second, committee service could also improve the political network of a deputy. Undoubtably personal connections did play a role in career advancement. But the informal connections among politicians, and how these influence careers, are unobserved and difficult to measure. However, we can look to observable measures of networking across deputies in the form of cosponsorship patterns. Both empirical research and network analysis have demonstrated that legislators who serve together on committees are more closely connected and more likely to cosponsor bills (Fowler 2006; Louwerse and Otjes 2015). If the causal effect of committee service was to create links with fellow budget committee members, then we would expect to see this reflected in an increased probability of authoring bills together.

Finally, distributive theories of legislative organization argue that committees primarily serve the constituency-based on demands of politicians and that committee membership aids in distributional targeting and gains from trade (Mayhew 1974; Weingast and Marshall 1988). Thus the effect of committee service could be the ability of committee members to achieve pork for their district. The Third Republic budget committee was the only standing committee during this era, ${ }^{10}$

tions to dramatically alter budgets, which increased the likelihood of cabinet dissolution Cox (2016)

10. The lack of a competitive committees system suggests that theories of intercommittee trading do not apply. However, there inevitably were other methods of informal logrolling in the chamber, that we do not address. Instead, we focus on one observable metric of individual behavior vis-à-vis pork, which is sponsorship. and it was also a relatively imprecise instrument with which to funnel pork back to constituencies, because budget chapters and their allocations were at the national level and very broad. To what extent deputies drafted the budget with their constituencies in mind is not easily identifiable. Instead, we explore if budget committee experience improves the ability of a deputy to initiate pork barrel legislation in the future. We examine the category of legislation primarily associated with pork barrel projects, which was credit and finance bills. If budget committee members improved their targeting through pork barrel trading in committee, then we would expect to see an increase in the probability of sponsoring credit and finance legislation.

\section{RESEARCH DESIGN}

The unique method of nomination via the bureaux allows us to use an instrumental variables design to identify the causal effect of committee membership on careers. Key to our identification strategy is the nomination procedure by which committee posts were assigned. Each autumn, the approximately 580 deputies of the Chamber would convene to select the 33 members of the budget committee. First, the entire Chamber was randomly assigned into the 11 bureaux. Next, deputies were given their assignment and then met in their respective groups. Finally, and within hours, each bureau then nominated three representatives from its ranks to serve on the budget committee (Barthélemy 1934).

Bureaux were temporary assignments, existing only for the budget committee selection, and were redrawn each year. Initially they were drawn up to two weeks before the nomination procedure began, but this was changed to hours before in 1894. This new, short time frame was designed to protect the budget committee from corruption or advance coordination by political groups (Gooch 1928). We make use of the random variation introduced by lottery into the selection process of the budget committee and exploit a deputy's characteristics within his randomly assigned bureau to isolate the effect of a budget committee nomination. These temporary bureaux serve as an instrument that is correlated with budget committee selection. Conceptually, the competitiveness of the randomly assigned group acts similarly to a form of encouragement design (Imai, Tingley, and Yamamoto 2013; Sekhon and Titiunik 2012).

Our empirical strategy uses an instrumental variable research design to estimate the effect of budget committee service on legislator careers. More specifically, we look at whether serving on the budget committee led to changes in legislative productivity as well as increased probabilities of higher office and reelection. These sections detail our data, the construc- 
tion of the instrument, and the assumptions behind the instrumental variable research design.

\section{Data and estimation sample}

We focus on a key period of party institutionalization in France, from the regime's inception to World War I. The main sample for our analysis, which we term the lottery sample, focuses on the effects of committee service from 1894 (when bureaux were drawn two hours prior to selection) to 1910 (when the randomized selection process was eliminated). The data are structured by deputy-year, and we were able to find complete budget information for $8,147 \mathrm{ob}$ servations, or maximum 1,330 individuals. Table 1 presents the yearly distribution of budget committee members, whether they had served on the budget committee the year before (Budget Incumbent), as well as whether they enter our lottery sample.

Data on individual covariates and career outcomes are drawn from a data set spanning the entire Third Republic, from 1877 to 1936. It includes individual-level and districtlevel data for deputies in the Chambre des députés, drawn from historical election results, the parliamentary records, biographical information, and census data. ${ }^{11}$ This information is matched to detailed lists of budget committee members, ministers, ${ }^{12}$ bureaux assignments, and lists of party leadership. As a result, we have the full legislative and career trajectories of all deputies who served in the lower chamber.

Our outcome variables measure legislative behavior and career success. To measure acquisition of expertise, we look at the policy-making activities of individual deputies, by examining bill sponsorship. ${ }^{13}$ To do so, we collect data on the complete set of roll call votes for the years 1894-1913, published daily in the official parliamentary record, the Journal officiel (Assemblée Nationale Française 1870-1910). The sample includes 4,615 bills, and each roll call vote listed the topic of the bill, its sponsors, and the full set of voting deputies. Approximately $50 \%$ of deputies in our roll call sample spon-

11. A detailed description of data sources can be found in the appendix.

12. The majority of ministers were chosen from within the Chamber (Heinberg 1931). A small proportion of ministers were not and are not included in the analysis.

13. The success of a bill could be related to events or chamber dynamics unmeasured in our data. Measuring a bill's success is difficultsome bills are proposed but disappear from the parliamentary record, some bills are divided and voted on by parts, and other bills are tabled for years. As a result, in the French context, legislative entrepreneurship is best measured using sponsorship.
Table 1. Budget Committees and Budget Incumbency

\begin{tabular}{lrrrl}
\hline Term and Year & All & Inc. & \% Inc. & Lottery Sample? \\
\hline 1893: & & & & \\
1894 & 33 & 13 & 39 & Yes \\
1895 & 33 & 14 & 42 & Yes \\
1896 & 33 & 12 & 36 & Yes \\
1897 & 33 & 19 & 58 & Yes \\
1898: & & & & \\
1898 & 33 & 6 & 18 & Yes \\
1899 & 33 & 31 & 94 & No \\
1900 & 33 & 15 & 45 & Yes \\
1901 & 33 & 16 & 48 & Yes \\
$1902:$ & & & & \\
1902 & 33 & 10 & 30 & Yes \\
1903 & 33 & 14 & 42 & Yes \\
1904 & 33 & 15 & 45 & Yes \\
1905 & 33 & 31 & 94 & No \\
$1906:$ & & & & \\
1906 & 33 & 12 & 36 & Yes \\
1907 & 33 & 16 & 48 & Yes \\
1908 & 33 & 18 & 55 & Yes \\
1909 & 33 & 21 & 64 & \\
Total & 528 & 263 & 49.6 & \\
\hline
\end{tabular}

Note. Budget incumbents (Inc.) defined as serving on the budget committee the year before. The lottery sample (our estimation sample) begins in 1894. In 1899 and 1905, the previous committee remained in place so that there is no information for selection in the bureaux. These years do not enter the lottery sample.

sored at least one bill in their career, and only $15 \%$ of the amendments in the sample were cosponsored.

Figure 1 presents the percentage of sample bills in each category and shows the topics that were most frequently discussed. Further information about these categories can be found in the appendix (available online), but it is important to distinguish among the different types of financial legislation. Budget amendments were bills proposed from the chamber floor to edit allocations within the broad budget chapters. We use these bills as a natural proxy for budget expertise learned in committee. Economic bills were less technical and more diverse; this category primarily included trade, taxes and tariffs on various industries, and regulations regarding the rail or marine transport of goods. As these bills were prevalent but did not feature financial expertise, they provide a useful robustness check for skill acquisition.

Credit and finance bills, on the other hand, consisted of singular transfers to finance a specific project and were much more targeted (Besson 1901). In our data, for example, in 1895 a credit was requested to fund the repair of a broken dike in the reservoir of Bouzy; in 1889, a credit bill was pro- 


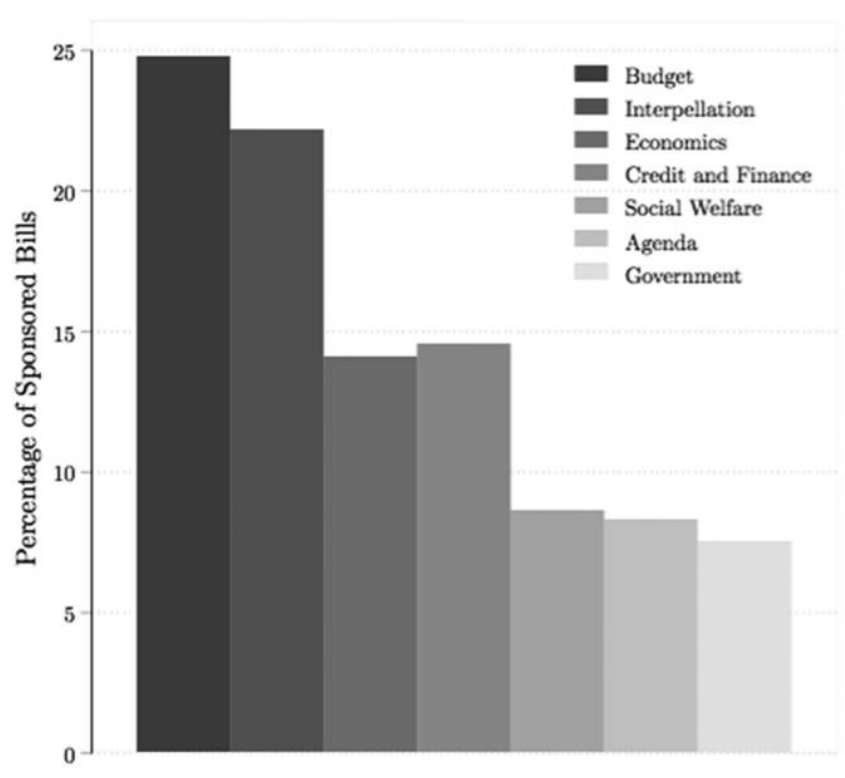

Figure 1. Main categories of sponsored bills, 1894-1913

posed for the creation of a telephone office in the southwest region of Paris; in 1902, an amendment to the existing finance law was proposed to fund the advancement of teachers; and in 1906, a line of credit was proposed to fund an organization to support the breeding of French horses. These were the Third Republic equivalent of pork barrel legislation and provide an observable test of distributive motivations.

Using these data, we construct a set of indicator variables, Sponsor, to measure legislative productivity across types of bills. We first measure whether a deputy sponsored any type of bill within five years after committee service and then construct similar variables for each type of bill, to better measure expertise and pork barrel politics. We also examine cosponsorship, by creating a variable Cosponsor that takes a value of 1 if a deputy cosponsors a bill of any type with another deputy. The variable Cosponsor within Budget Committee Network specifies that the deputy cosponsored with someone who served on a current or past budget committee.

We are also interested in the acquisition of higher office. We define a set of dependent variables, equal to 1 if the deputy served in a ministerial position, Minister; leadership post in a partisan governing committee, Leader; or was elected to the senate, Senate, for the first time within $t+5$ years. By considering the first service we can avoid reverse causality concerns. In our sample, 65 (5\%) deputies in our sample served as a minister, 141 (11\%) held a leadership post in a party governing committee, and 50 (4\%) were elected to the senate. We look at electoral effects, and here we look at both the choice to run for reelection and (conditional on running) whether the deputy was successful. It is important to separate these outcomes because if budget committee service had career benefits (e.g., if these deputies were more likely to obtain senatorial or ministerial appointments), this would bias any estimates of reelection success. We create a indicator variable called Ran Next that takes a value of 1 if the deputy chose to run for reelection, and two indicator variables that measure whether a deputy was reelected in the term immediately following his budget service, One Term, or two terms later, Two Terms. Models using reelection success only include deputies that chose to run.

We consider a number of pretreatment covariates as controls. To measure wealth, we create an indicator variable of the wealthiest occupational category: Upper Class identifies aristocratic or bourgeois landowners. Liberal Profession is a measure of professional qualifications and identifies bourgeoisie: doctors, lawyers, and bankers. We also create a dichotomous variable that measures whether a deputy had prior experience as a civil servant or appointed government representative, called Civil Service. Other deputy characteristics include Age and Parliamentary Experience, both measured in years. As district characteristics inevitably affect a deputy's career, we include district size to proxy for political capital (measured by the number of registered voters, Electors), whether the deputy was from the capital (Paris), and competition (measured by electoral margin, Electoral Margin).

\section{Instrument}

The instrument utilizes the randomization of legislative bureaux in the selection process and measures the likelihood that an individual deputy will advance from the bureaux to the budget committee. We construct an instrument specific to each deputy $i$ in each year $t$, equal to the number of deputies $(j \neq i)$ within his randomly assigned bureau $b$ who served on the previous budget committee. Thus the instrument measures the number of budget incumbents in the bureau, excluding the deputy. This continuous instrument is a measure of how likely the deputy would be to win the nomination; if many of his competitors in his bureau served on the previous budget committee, then it was less likely that he would advance to the budget committee (and vice versa). The instrument exploits the random assignment of budget incumbents to bureaux, or whether there were any "free spots," which introduced variation in individual promotion opportunities. ${ }^{14}$

Other Budget Incumbents $s_{i, b, t}=\sum_{j \neq i}$ Budget Incumbent $_{j, b, t}$.

14. The expected value of our instrument could be correlated with a deputy's own budget incumbency status, but our instrumental variable 
Historical and cross-national evidence supports the use of past budget experience as the primary criterion for selection. Lowell's (1902) formidable study of the French committee system argues that this was the case, and historical evidence also supports the claim that those most interested and experienced in this issue area would be put forward (Gooch 1928). While there are no written records of the nomination process that took place within the bureaux, we know that it happened quickly, within a single legislative session. The large legislature with weak parliamentary groupings provided few natural foci of coordination, and the short timing of selection made partisan bargaining virtually impossible. Prior budget experience therefore served as an advantage. ${ }^{15}$ Recalling table 1, our sample clearly shows that budget incumbents were likely to be reselected to the budget committee: on average $50 \%$ of budget committee members were individuals who had served on the previous year's budget committee. For this reason, our instrument uses budget incumbency to measure the competitiveness of the selection environment a deputy faced in his bureau each year.

Our instrumental variable research design relies on the following assumptions: (i) the bureaux were truly randomly drawn; (ii) the instrument is relevant, and has a nonzero causal effect on budget committee nomination; and (iii) the measure does not violate the exclusion restriction, for example, the number of budget committee incumbents in a deputy's bureau had no direct effect on our outcomes of interest. We discuss each of these in turn.

Verifying the random assignment. The research design relies on random variation introduced by lottery into the selection process of the budget committee. There is no historical evidence to suggest manipulation or tampering with assignment of the bureaux. Still, we tested whether the assignment of individuals into bureaux was likely to have been truly random following a fair lottery. Figure 2 compares a randomly drawn bureau (bureau no. 1) and any other specific bureau, within each budget committee year. It confirms that there are almost no significant differences between the groups. The few differences that appear are not systematic: they disappear with pairwise comparison of the different bureaux using different ones as the base comparison group. Moreover,

strategy only requires that the instrument is randomly assigned conditional on covariates. For that reason, we always present results with and without individual controls. We also find no evidence for heterogeneous treatment effects for budget incumbents. More detailed discussion and the heterogeneous treatment results can be found in the appendix.

15. The US House of Representatives post-1870 documented a very similar budget incumbency advantage in its committee system (Katz and Scala 1996).

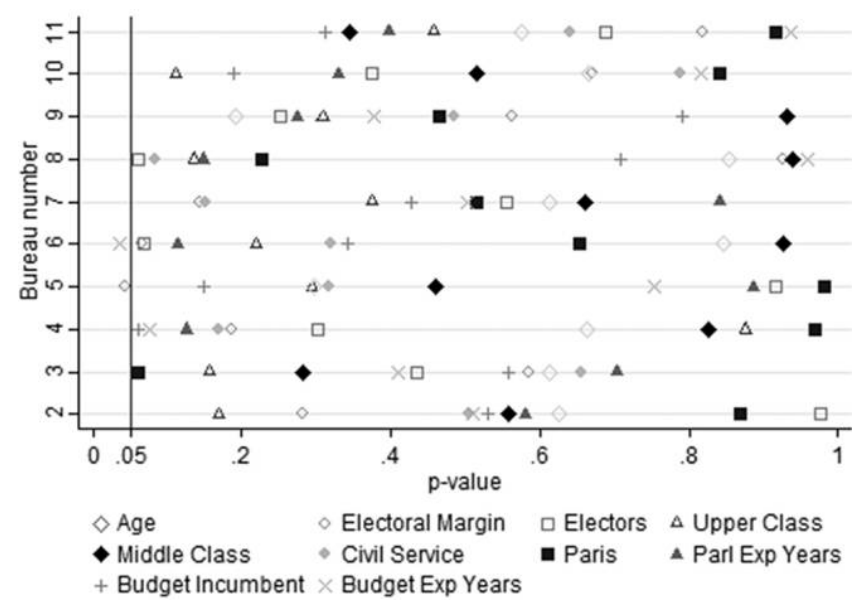

Figure 2. Balance in characteristics ( $p$-values). Graph depicts distribution of $p$-values from regressing characteristics of deputies serving in randomly drawn and numbered bureaux between 1894 and 1909, excluding 1899 and 1905 on bureau number. All models include year dummies. Two-way clustered standard errors at individual and bureau-year level. Characteristics with $p$-values smaller than $5 \%$ signify significant differences at the $5 \%$ level of a given bureau to bureau 1 (the baseline bureau). Full results in appendix.

we confirmed that the instrument cannot systematically predict pretreatment covariates determined before budget committee nominations (see fig. 3). Still to account for potential imbalances in pretreatment covariates of legislators across bureaux, we include results from analyses in which we control for these potentially unbalanced characteristics.

Exclusion restriction and instrument relevance. This instrument is valid only if the number of other budget incumbents of a deputy's bureau is first correlated with budget committee membership (instrument relevance) and, second, affects the legislative behavior, higher office, or reelection only via a deputy's budget committee appointment (exclusion restriction). While a deputy's own budget incumbency status is endogenous and potentially related to omitted variables such as talent or skill, the budget incumbency of other bureau members is plausibly orthogonal to a deputy's own characteristics after each new random draw. It was precisely the composition of a deputy's bureau that, aside from such individual factors, determined his chances of selection at any given point in time.

First, there is significant support for instrument relevance, as the strong first-stage results indicate. We report the Kleibergen-Paap Wald F-statistics, which range from 50 to over 200. The relevant first-stage coefficient of the instrument is reported in the main results table. Full first-stage results can be found in the appendix. Overall, the higher the number of incumbent competitors in a deputy's bureau, the less likely that the deputy would advance to the budget committee. 

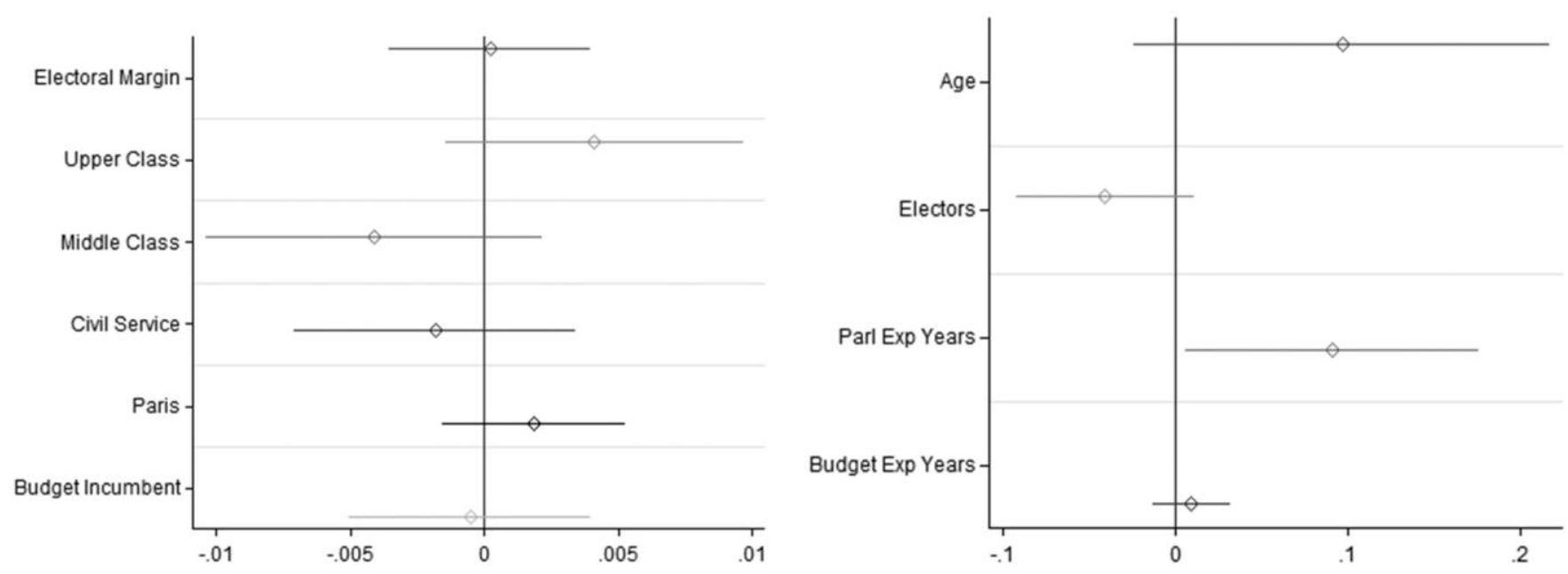

Figure 3. Pretreatment covariates and instrument. Estimates from regressing pretreatment characteristics on the instrument for deputies serving between 1894 and 1910, excluding 1899 and 1905. All specifications include year dummies. Two-way clustered standard errors at individual and bureau-year level. Full results in appendix.

Second, the cornerstone of the French case is that bureaux were not only randomly assigned but also existed temporarily and for the sole purpose of budget committee elections. These groups ceased to exist after appointing the budget committee members, which eliminated any type of long-term coordination, and they had no other legislative function. There was no prestige or honor attached to being in a particular bureau; it was an administrative tool, and bureaux were always redrawn before the next appointments took place. Therefore, it is highly unlikely that the composition of a deputy's randomly assigned bureau had an effect on any other outcome except immediate selection to the budget committee.

\section{Instrumental variables regression specification}

We estimate the following second-stage least squares regression:

$$
Y_{i, t}=\beta_{0}+\beta_{1} \text { Budget }_{i, t}+\beta_{2} X_{i, t}+\eta_{t}+\varepsilon_{i, t},
$$

in which $Y_{i, t}$ are individual deputy career outcomes, Budget ${ }_{i, t}$ is an indicator for serving on the budget committee in the corresponding year $t, X_{i, t}$ is a vector of individual controls, and $\varepsilon_{i, t}$ is the error term. The individual controls include budget incumbency, as well as age, district size, margin of victory, parliamentary experience and their squares; and indicator variables for upper class, middle class, civil service experience, and whether the deputy represents a Parisian district. Each specification also includes $\eta$ year dummies. Standard errors are two-way clustered at both individual and bureau-year level, because individuals enter into several yearly lotteries over the course of their career and the treatment is similar for individuals within each bureau in a specific year.
The instrument employed to estimate budget committee membership in the first stage for the model of equation (2) is Other Budget Incumbents, calculated for each $i$ at time $t$ as a function of their bureau $b$. Correspondingly, the first stage is estimated as follows.

$$
\begin{aligned}
\text { Budget }_{i, b, t}= & \gamma_{0}+\gamma_{1} \text { Other Budget Incumbents } \\
& +\gamma_{2} X_{i, t, t}+\eta_{t}+\nu_{i, b, t} .
\end{aligned}
$$

A possible concern is that our instrument picks up not only how competitive the selection environment is, but also the initial quality of those that survive selection. This is precisely why we control for observable individual pretreatment characteristics, including age, experience, career, and social class. However, to further address this concern, we also present our main results including individual fixed effects. Any remaining effect of the instrument after including individual fixed effects cannot be capturing initial differences between individuals.

\section{RESULTS}

\section{Committee service and legislative productivity}

We are first interested in the benefits to an individual legislator that accrue from committee service. If budget committee members acquire unique expertise, this should be positively reflected in their future legislative productivity. Therefore, we look at the policy-making activities of individual deputies, measured by the number of bills a deputy sponsored. Deputies had the right of unlimited individual initiative and could claim credit for a bill. We find that deputies who serve on the budget committee are more likely 
Table 2. Budget Committee and Future Budget Bill Sponsorship

\begin{tabular}{|c|c|c|c|c|c|c|}
\hline Sponsor Budget Bill <5 Years & $\begin{array}{l}\text { OLS } \\
(1)\end{array}$ & $\begin{array}{l}\text { OLS } \\
(2)\end{array}$ & $\begin{array}{l}\text { OLS } \\
(3)\end{array}$ & $\begin{array}{c}\text { 2SLS } \\
(4)\end{array}$ & $\begin{array}{l}2 \text { SLS } \\
(5)\end{array}$ & $\begin{array}{c}2 \text { SLS } \\
(6)\end{array}$ \\
\hline Budget committee & $\begin{array}{l}.062^{\star * \star} \\
{[.023]}\end{array}$ & $\begin{array}{c}.030 \\
{[.019]}\end{array}$ & $\begin{array}{c}-.007 \\
{[.019]}\end{array}$ & $\begin{array}{l}.644^{\star * *} \\
{[.236]}\end{array}$ & $\begin{array}{l}.634^{\star * *} \\
{[.233]}\end{array}$ & $\begin{array}{l}.496^{\star * *} \\
{[.182]}\end{array}$ \\
\hline Observations & 8,147 & 8,147 & 8,066 & 8,147 & 8,147 & 8,066 \\
\hline Individual controls & No & Yes & Yes & No & Yes & Yes \\
\hline Individual fixed effects & No & No & Yes & No & No & Yes \\
\hline
\end{tabular}

First Stage: Dependent Variable Is Budget Committee

Instrument

Other budget incumbents

Kleibergen-Paap F-statistic

$\begin{array}{ccc}-.009^{* * *} & -.008^{* * *} & -.010^{* * *} \\ {[.001]} & {[.001]} & {[.001]} \\ 51.77 & 234.01 & 79.91\end{array}$

Note. Estimates for 1,330 deputies (1,249 deputies with individual fixed effects in cols. 3 and 6) serving between 1894 and 1910, excluding 1899 and 1905. All specifications include year dummies. Individual controls include age, district size, margin of victory, parliamentary experience and their squares, upper class, middle class, civil service experience, Paris, and budget incumbency. Two-way clustered SE at individual and bureau-year level.

${ }^{*} p<.1$.

${ }^{* *} p<.05$.

${ }^{* * *} p<.01$.

to sponsor budget amendments within five years of their committee service. The detailed estimates for amendments to the yearly budget are presented in table 2 . On average, the standard ordinary least squares (OLS) results show that deputies who served on the budget committee were only slightly more likely to increase their future budget bill sponsorship activity (col. 1), and there is no effect if we account for individual idiosyncrasies using controls or fixed effects (cols. 2 and 3).

Yet we see very different estimates when we employ the preferred instrumental variables (IV) estimation strategy. Here, those who served on the budget committee are much more likely to sponsor a budget amendment in the next five years, with probabilities ranging from $50 \%$ to $64 \%$. These are significant and large effects. They could indicate that the association between budget committee service and activity is biased downward (cols. 1-3). Precisely the committee members selected were much more likely to increase their legislative activity, as shown by the large local average treatment effects on those selected as a result of a favorable bureau draw (cols. 4-6).

The fact that the local average treatment effect remains much larger after the inclusion of individual fixed effects (col. 6) suggests that selection of initially high-quality types cannot fully explain the increased legislative behavior of the selected and that there was learning by doing as a result of budget committee service. ${ }^{16}$ These results are also not being driven by budget committee members submitting bills the year they are also serving on the committee - not only was this customarily rare, less than 30 bills in a large sample, but the results remain robust to the exclusion of those deputies.

To further strengthen our conclusions, we next consider sponsorship of different types of legislation to assess whether the learning was specific to budget legislation. In further support of the expertise mechanism, we only find effects for bills relating to the budget. Figure 4 demonstrates the probability of bill sponsorship within five years across the range of bill categories - budget, interpellation, economics, government, and social welfare. This is intuitive and lends support to the concept that deputies were learning on the job; if deputies gained specific skills in drafting legislation as a result of committee service, then we would expect this experience to be more likely to influence the production of bills requiring similar knowledge. These results are not only suggestive of the fact that a deputy gained expertise concerning financial policy making from committee service, but that this

16. If there was no learning and committee service instead only provided reputational (signaling) advantages, we should not observe these large treatment effects on budget bill sponsorship. Moreover, we do not observe similar effects on cosponsorship, providing further evidence in favor of specialization, not mere signaling. 


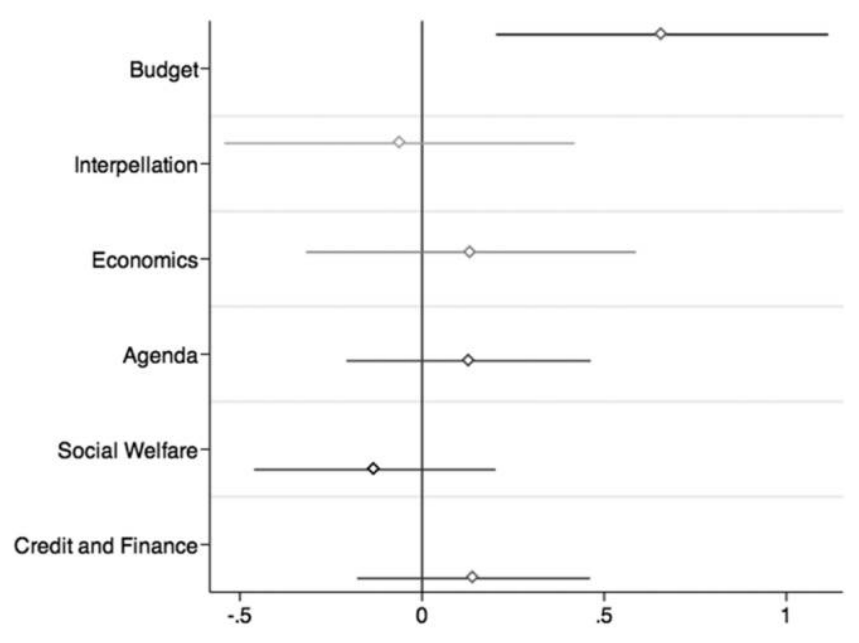

Figure 4. Estimates of committee service on sponsorship by category, 1894-1913. Two-stage least squares estimates for deputies serving between 1894 and 1910, excluding 1899 and 1905. Two-way clustered standard errors at individual and bureau-year level. Dependent variable is sponsoring bill within five years of committee service.

was particularly relevant for those legislators who were lucky to have obtained those positions in the first place (cols. 4-6 in table 2). This indicates that the within-legislature career value of the committee post acts through learning and the acquisition of specialized expertise.

\section{Committee service and higher office}

We now investigate the relationship between committee experience and career success. We examine three types of prestigious political positions: minister, partisan parliamentary group leader, and senator. All three types of positions would have been considered beneficial and desirable to a career politician. We estimate the effect of budget committee membership on the probability that a deputy will gain one of these positions within five years of committee appointment. Figure 5 presents the second-stage coefficient of budget committee service on each of our three outcomes derived from our two-stage least squares (2SLS) analysis. The three coefficients presented for each type of career outcome are from models without individual controls (model 1), including individual controls (model 2), as well as individual fixed effects (model 3). ${ }^{17}$

Serving on the budget committee increases the probability of obtaining a first ministerial position in the next five years by as much as $28 \%$. Even after including individual fixed effects, we still find an increase of $15 \%$ in the probability of obtaining a ministerial post in the next five years.

17. Full results can be found in the appendix.
Note that the first stage remains the same as in table 2, so that the instrument in the first stage is still a strongly significant predictor of budget committee selection. These results confirm the clear link between budget committee service and first ministerial appointments. Obtaining a seat on the budget committee significantly improved career prospects, in a relatively short amount of time.

While budget committee membership had a positive effect on ministerial appointment, this was not the case for partisan leadership or senatorial positions. We find no statistically significant effect in any specification, despite the strongly predictive first stage. Likewise, individuals with budget committee experience are no more likely to enter the senate than individuals without such experience. These results show an interesting pattern-committee experience helps advance a deputy's career, but only in terms of the ministry. So what explains the positive effect of budget committee service on ministerial positions and not other types of higher office?

Recalling our first set of results, that committees enhance productivity through newly gained expertise, it may be that ministerial selection was more likely to favor skilled deputies because the role of a minister and his portfolio required enhanced skills. Further, appointing a former budget member to the ministry, regardless of the portfolio, could help ensure that the cabinet spent the finances as the powerful budget committee desired (e.g., Cox 2016) and thus solve issues with moral hazard. It is also likely that selection for

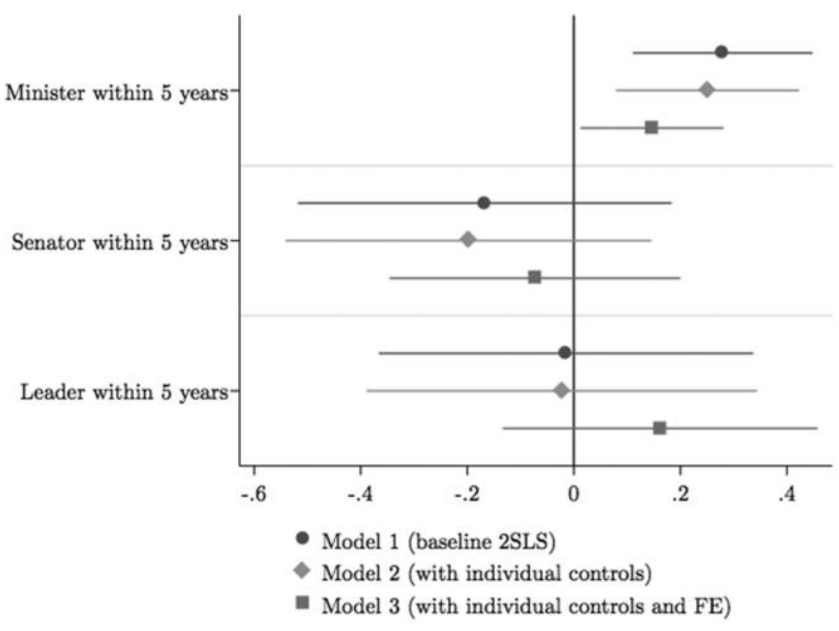

Figure 5. Estimates of committee service on career outcomes within five years, 1894-1913. Models are two-stage least squares estimates for deputies serving between 1894 and 1910, excluding 1899 and 1905. Two-way clustered standard errors at individual and bureau-year level. All specifications include year dummies. Individual controls include age, district size, margin of victory, parliamentary experience and their squares, upper class, liberal profession, civil service experience, Paris, and budget incumbency. 
either parliamentary groups or the senate relied on nontechnical criteria, potentially based on characteristics external to the legislature (such as loyalty in local party activities or the competitiveness of senatorial elections). Therefore we argue that if the within-legislature career value of the committee post acts through learning and the acquisition of specialized expertise, then we would expect to find a stronger effect for higher office that would require such knowledge.

\section{Alternative explanations}

Finally, we address alternative explanations for our findings. We have shown that committees bestow specific legislative expertise on their members, and we argue that this expertise helps individuals obtain certain types of higher office. But committee service could explain career success in other ways; it could boost a deputy's reputation, aid in political networking, or improve a deputy's ability to target resources to his constituency. As a result, to explore these channels, we analyze observable legislative or electoral behavior that provides a plausible test for each mechanism.

First, we examine whether serving on a high profile committee could improve a deputy's reputation. In the Third Republic, the budget committee was highly visible; it was discussed daily in both national and local newspapers (Garner 1914; Gooch 1928), and deputy qualifications were frequently invoked in print in the period leading up to each national election. For these reasons, it is plausible to assume that any reputational effect of past budget experience would most likely operate through the mechanism of reelection. A number of historical references mention the importance of the budget committee in the reelection prospects of deputies (Chapman 1962; Dogan 1979; Gooch 1928) in addition to a large observational literature on committee membership.

We estimate the effect of budget committee membership on electoral success. We use the same empirical strategy and estimate in table 3 whether committee membership results in reelection in the next electoral cycle or in two terms, conditional on running. We also look to see whether it affects a deputy's choice to run for election (vs. retire or seek other employment). The same set of controls is used, which includes deputy characteristics, district controls, and measures of competition.

If the mechanism was in any way reputational, we would expect to see a difference in either reelection or decisions to run. However, we find no statistically significant effect of budget service on reelection, within the following term or within two terms (table 3, cols. 1-4). Budget service also has no impact on a deputy's choice to run for reelection the following term (col. 5), and this is the case even when controlling for size and competitiveness of the district (col. 6).

Table 3. Reelection, within the Next Two Terms

\begin{tabular}{|c|c|c|c|c|c|c|}
\hline & \multicolumn{4}{|c|}{ Reelected } & \multirow[b]{2}{*}{$\begin{array}{c}\text { Ran Next } \\
\text { (5) }\end{array}$} & \multirow[b]{2}{*}{$\begin{array}{c}\text { Ran Next } \\
\text { (6) }\end{array}$} \\
\hline & $\begin{array}{c}\text { One Term } \\
\text { (1) }\end{array}$ & $\begin{array}{c}\text { One Term } \\
\text { (2) }\end{array}$ & $\begin{array}{c}\text { Two Terms } \\
\text { (3) }\end{array}$ & $\begin{array}{c}\text { Two Terms } \\
\text { (4) }\end{array}$ & & \\
\hline \multirow[t]{2}{*}{ Budget committee } & -.395 & -.570 & -.157 & -.236 & .341 & .293 \\
\hline & {$[.380]$} & {$[.455]$} & {$[.317]$} & {$[.401]$} & {$[.850]$} & {$[.923]$} \\
\hline Observations & 2,014 & 2,014 & 2,014 & 2,014 & 2,528 & 2,528 \\
\hline Individual controls & No & Yes & No & Yes & No & Yes \\
\hline
\end{tabular}

First Stage: Dependent Variable Is Budget Committee

Instrument

\begin{tabular}{lcccccc} 
Other budget incumbents & $-.013^{* * *}$ & $-.010^{* * *}$ & $-.013^{* * *}$ & $-.010^{* * *}$ & $-.012^{* *}$ & $-.010^{* * *}$ \\
& {$[.003]$} & {$[.002]$} & {$[.003]$} & {$[.002]$} & {$[.002]$} & {$[.001]$} \\
Kleibergen-Paap F-statistic & 16.04 & 36.00 & 16.04 & 36.00 & 23.13 & 51.84 \\
\hline
\end{tabular}

Note. Term-level estimates for 1,086 deputies (1,319 deputies in cols. 5 and 6) serving between 1894 and 1910, excluding 1899 and 1905 . All specifications include year dummies. Individual controls include age, district size, margin of victory, parliamentary experience and their squares, upper class, liberal profession, civil service experience, Paris, and budget incumbency. Two-way clustered standard errors at individual and bureau-year level.

$\star p<.1$.

${ }^{* *} p<.05$.

${ }^{* * *} p<.01$. 
These findings in particular echo results found by the two previously mentioned studies that used natural experiments to isolate the causal impact of committee assignments. In the context of US congressional and state legislators, both Kellerman and Shepsle (2009) and Broockman and Butler (2015) find that committee service does not translate into a measurable electoral benefit. While committees can be career enhancing, they seem to have no electoral effect.

Another alternative explanation we consider is networks. Perhaps serving in a committee also provides a legislator with a valuable set of personal connections, and it is this network that can explain career success. We choose to test this by using observable patterns of political networks, as measured by bill cosponsorship. We consider whether a deputy cosponsored bills together with at least one deputy who served on a (current or past) budget committee, within the next five years. Table 4 presents the results. While there is some evidence that those serving on budget committees on average cosponsor more with budget committee members within five years (col. 1), the effect is smaller after including individual controls (col. 2) and becomes negative and statistically insignificant after including individual fixed effects (col. 3). Using our IV strategy instead, we find positive but no statistically significant effects of serving on the budget committee and cosponsoring with (past or current) budget committee members (cols. 4-6). While admittedly only one measure of personal connections, theoretically this would be the legislative behavior most likely to be observed, and still we find no conclusive evidence for network effects. Therefore, networks, like reputation, do not seem more important than skill acquisition in explaining the value of committees for careers.

Finally, distributional theories argue that committees serve as a forum in which legislators can obtain resources or pork for their districts. Yet in the Third Republic, the annual budget consisted of national budgetary allocations and, therefore, was a very broad tool in which to target individual districts. Instead, deputies used their individual proposal rights to propose bills exclusively initiating pork barrel projects. We coded these as credit and finance legislation and included them in our analysis of legislative bill sponsorship discussed previously. If budget committee members improved their targeting through pork barrel trading in committee, then we would expect to see an increase in the probability of sponsoring credit and finance legislation. Recalling figure 4, we find no effect on these types of bills.

\section{CONCLUSION}

We exploited a unique natural experiment in the French Third Republic to show an independent effect of committee service on careers, an important assumption in past literature that eluded identification. We demonstrated that specialized information acquisition is a primary explanation for

Table 4. Future Bill Cosponsorship in Budget Committee Networks

\begin{tabular}{lcccccc}
\hline & OLS & OLS & OLS & 2SLS & $\begin{array}{c}\text { 2SLS } \\
(5)\end{array}$ & $\begin{array}{c}\text { 2SLS } \\
(6)\end{array}$ \\
\hline Cosponsor Bill in Budget Committee Network $<5$ Years & $(1)$ & $(2)$ & $(3)$ & $(4)$ & .264 & .103 \\
Budget committee & & & & & & \\
& $.101^{* * *}$ & $.068^{\star * *}$ & -.026 & .292 & {$[.278]$} & {$[.223]$} \\
Observations & {$[.025]$} & {$[.021]$} & {$[.022]$} & {$[.287]$} & 8,147 & 8,066 \\
Individual controls & 8,147 & 8,147 & 8,066 & 8,147 & Yes & Yes \\
Individual fixed effects & No & Yes & Yes & No & No & Yes
\end{tabular}

First Stage: Dependent Variable Is Budget Committee

Instrument

Other budget incumbents

Kleibergen-Paap F-statistic

\begin{tabular}{lcc}
$-.009^{\star * *}$ & $-.008^{* * *}$ & $-.010^{* * *}$ \\
{$[.001]$} & {$[.001]$} & {$[.001]$} \\
51.77 & 234.01 & 79.91 \\
\hline
\end{tabular}

Note. Estimates for 1,330 deputies (1,249 deputies with individual fixed effects in cols. 3 and 6) serving between 1894 and 1910, excluding 1899 and 1905. All specifications include year dummies. Individual controls include age, district size, margin of victory, parliamentary experience and their squares, upper class, middle class, civil service experience, Paris, and budget incumbency. Two-way clustered SE at individual and bureau-year level.

$* p<.1$.

${ }^{* *} p<.05$.

${ }^{* * *} p<.01$ 
why it is valuable to legislators to gain committee experience in order to further their individual careers. The evidence we presented is strongly consistent with this learning mechanism: budget committee experience makes a legislator more likely to sponsor a budget bill and to obtain a ministerial post in the future yet has no effect on behavior in other policy areas. Our results are robust to different individual control strategies. Therefore, while more competitive bureaux may select more stringently on preexisting political quality, our set of findings allows us to exclude that such selection alone explains specialization.

We also explored alternative channels, such as reputation, network effects, and pork barrel legislation, but find no results. Legislators see no electoral benefits, as reflected in reelection probabilities, and are no more likely to cosponsor with budget members or initiate pork barrel legislation. Yet it is possible that budget committee members developed an internal reputation and therefore provided focal points for legislative coalition building. It equally could be that this internal reputation also helped legislators secure ministerial posts, not only because they were viewed as being effective but also because appointing a former budget member to the ministry solved moral hazard problems by ensuring that the ministry spent the finances as the budget committee intended (e.g., Cox 2016). However, this focality would still be activated by expertise; we find no effect on cosponsorship within past budget committee networks or career progression in roles where focality could be similarly useful but does not require specialization (e.g., party leadership or senatorial positions). Taken together, we conclude that specialized skills drive the value of committee service.

One contribution of this paper is to explain information acquisition in the absence of restrictive amendment rules. Another contribution is to demonstrate that there can be incentives for specialization across varying parliamentary systems. This study underlines the importance of applying and testing theories of committee specialization beyond the US context and joins a growing literature using microlevel data to advance the comparative study of legislative institutions. Finally, knowing the potentially positive effect of committee service on individual legislators also brings up a larger debate about what types of selection mechanisms to use (Cirone and Van Coppenolle 2016). It is clear that the bureaux system expanded the opportunities for expertise acquisition across the many deputies within the assembly. Even in the absence of a party-controlled selection or amendment process, individual career incentives led legislators to specialize. Overall, our results show the importance of committees as a stepping stone to higher office, even in the absence of disciplined party institutions.

\section{ACKNOWLEDGMENTS}

We would like to thank John Huber, Torun Dewan, Stephane Wolton, Christopher Kam, Isabela Mares, Jan Rovny, David Willumsen, Alexander Fouirnaies, and Michael Becher, and members of the Historical Political Economy Working Group and the Political Science and Political Economy (PSPE) group at the LSE. We also thank Jeff Jenkins, and our anonymous reviewers for their extremely helpful feedback. Previous versions of this manuscript were presented at the American Political Science Association, European Political Science Association, MPSA, European Consortium for Political Research Joint Sessions, the Council on European Studies Graduate Workshop on Comparative Historical Research on Europe, the Dutch Political Science Association, Sciences Po LIEPP, Bremen, PolEcon UK, London School of Economics Political Science and Political Economy Workshop, and the LSE Historical Political Economy Conference; we thank these seminar and conference audiences.

\section{REFERENCES}

Anderson, William, Janet M. Box-Steffensmeier, and Valeria SinclairChapman. 2003. "The Keys to Legislative Success in the U.S. House of Representatives." Legislative Studies Quarterly 28 (3): 357-86.

Assemblée Nationale Française. 1870-1910. "Documents parlementaires." Journal officiel de la République française. http://gallica.bnf.fr.

Barnett, Arthur, and Peter Carty. 2008. The Athenian Option: Radical Reform for the House of Lords. Charlottesville, VA: Imprint Academic.

Baron, David P. 2000. "Legislative Organization with Informational Committees." American Journal of Political Science 44 (3): 485-505.

Baron, David P., and John A. Ferejohn. 1989. "Bargaining in Legislatures." American Political Science Review 83 (4): 1181-206.

Barthélemy, Joseph. 1934. Essai sur le travail parlementaire et le système des commissions. Paris: Librairie Delagrave.

Berry, Christopher, and Anthony Fowler. 2016. "Cardinals or Clerics? Congressional Committees and the Distribution of Pork." American Journal of Political Science 60 (3): 692-708.

Besson, Emmanuel. 1901. Le controle des budgets en France et à l'etranger. 2nd ed. Paris: A. Chevalier Marescq.

Bodley, John. 1898. France: The Parliamentary System. London: Macmillan. Bowler, Shaun. 2010. "Private Members' Bills in the UK Parliament: Is There an Electoral Connection?" Lournal of Legislative Studies 16 (4): 476-94.

Bowler, Shaun, and David Farrell. 1995. "The Organizing of the European Parliament: Committees, Specialization and Co-ordination.” British Iournal of Political Science 25 (2): 219-43.

Broockman, David, and Daniel Butler. 2015. "Do Better Committee Assignments Meaningfully Benefit Legislators? Evidence from a Randomized Experiment in the Arkansas State Legislature." Iournal of Experimental Political Science 2 (2): 152-63.

Buchstein, Hubertus, and Michael Hein. 2009. "Randomizing Europe: The Lottery as a Decision-Making Procedure for Policy Creation in the EU." Critical Policy Studies 3 (1): 29-57.

Chapman, Guy. 1962. The Third Republic of France. New York: St. Martin's. Cirone, Alexandra, and Brenda Van Coppenolle. 2016. "Lottery-Based Procedures and Early Parliamentarization." Unpublished manuscript, London School of Economics and Political Science and Leiden University. 
Cox, Gary. 2016. Marketing Sovereign Promises: Monopoly Brokerage and the Growth of the English State. New York: Cambridge University Press. Cox, Gary, and Matthew McCubbins. 1993. Legislative Leviathan: Party Government in the House. Berkeley: University of California Press.

Cox, Gary, and William Terry. 2008. "Legislative Productivity in the 93rd105th Congresses." Legislative Studies Quarterly 33 (4): 603-18.

Crisp, Brian F., Maria C. Escobar-Lemmon, Bradford S. Jones, Mark P. Jones, and Michelle M. Taylor-Robinson. 2009. "The Electoral Connection and Legislative Committees." Journal of Legislative Studies 15 (1): 35-52.

Diermeier, Daniel. 1995. "Commitment, Deference, and Legislative Institutions." American Political Science Review 89 (2): 344-55.

Dogan, Mattei. 1967. "Les filières de la carrière politique en France." Revue Francaise de Sociologie 8 (2): 468-92.

Dogan, Mattei. 1979. "How to Become a Cabinet Minister in France: Career Pathways, 1870-1978." Comparative Politics 12 (1): 1-25.

Eggers, Andrew, and Arthur Spirling. 2014. "Guarding the Guardians: Legislative Self-Policing, Corruption and Judicialization in Victorian Britain." Quarterly Journal of Political Science 9 (3): 337-70.

Epstein, David, David Brady, Sadafumi Kawato, and Sharyn O'Halloran. 1997. "A Comparative Approach to Legislative Organization: Careerism and Seniority in the United States and Japan." American Journal of Political Science 41 (3): 965-98.

Fenno, Richard F. 1978. Home Style: House Members and Their Districts. Glenview, IL: Scott, Foresman.

Fowler, James H. 2006. "Connecting the Congress: A Study of Cosponsorship Networks." Political Analysis 14 (4): 456-87.

Garner, James. 1914. "Cabinet Government in France." American Political Science Review 8 (3): 353-74

Gilligan, Thomas W., and Keith Krehbiel. 1987. "Collective DecisionMaking and Standing Committees: An Informational Rationale for Restrictive Amendment Procedures." Journal of Law, Economics, and Organization 3 (2): 287-335.

Gilligan, Thomas W., and Keith Krehbiel. 1989. "Asymmetric Information and Legislative Rules with a Heterogeneous Committee." American Journal of Political Science 33 (2): 459-90.

Gilligan, Thomas W., and Keith Krehbiel. 1990. "Organization of Informative Committees by a Rational Legislature." American Journal of Political Science 34 (2): 531-64.

Gooch, Robert K. 1928. "The French Parliamentary Committee System." Economica 23 (June): 147-58.

Grimmer, Justin, and Eleanor Powell. 2013. "Congressmen in Exile: The Politics and Consequences of Involuntary Committee Removal.” Lournal of Politics 75 (4): 907-20.

Hedlund, Ronald D., Kevin Cooms, Nancy Martorano, and Keith E. Hamm. 2011. "Partisan Stacking on Legislative Committees." Legislative Studies Quarterly 34 (2): 175-91.

Heinberg, John G. 1931. “The Personnel of French Cabinets, 1871-1930.” American Political Science Review 25 (2): 389-96.

Huber, John. 1996. Rationalizing Parliament: Legislative Institutions and Party Politics in France. Cambridge: Cambridge University Press.

Huber, John, and Cecilia Martinez-Gaillardo. 2004. "Cabinet Instability and the Accumulation of Experience: The French Fourth and Fifth Republics in Comparative Perspective." British Journal of Political Science 34 (1): 27-48.

Imai, Kosuke, Dustin Tingley, and Teppei Yamamoto. 2013. "Experimental Designs for Identifying Causal Mechanisms." Journal of the Royal Statistical Society A 176 (1): 5-51.

Jones, Mark, Sebastian Saiegh, and Pablo Spiller. 2002. “Amateur LegislatorsProfessional Politicians: The Consequences of Party-Centered Electoral Rules in a Federal System." American Journal of Political Science 46 (3): 656-69.

Kam, Christopher, and Indridi Indridason. 2009. "Cabinet Dynamics and Ministerial Careers in the French Fifth Republic.” In Keith Dowding and Patrick Dumont, eds., The Selection of Ministers in Europe: Hiring and Firing. London: Routledge, 41-57.

Katz, Jonathan, and Brian Sala. 1996. "Careerism, Committee Assignments, and the Electoral Connection." American Political Science Review 90 (1): 21-33.

Kellermann Michael. 2014. "Do Oversight Responsibilities Encourage Legislative Specialization? Evidence from the British House of Commons." Unpublished manuscript, US Naval Academy.

Kellermann, Michael, and Kenneth A. Shepsle. 2009. "Congressional Careers, Committee Assignments, and Seniority Randomization in the US House of Representatives." Quarterly Journal of Political Science 4 (2): 87-101.

Khmelko, Irina, Charles Wise, and Trevor Brown. 2010. "Committees and Legislative Strengthening: The Growing Influence of Committees in Ukraine's Legislative Process." Journal of Legislative Studies 16 (1): 73-95.

Krehbiel, Keith. 1991. Information and Legislative Organization. Ann Arbor: University of Michigan Press.

Krehbiel, Keith. 2004. "Legislative Organization." Lournal of Economic Perspectives 18 (1): 113-28.

Loewen, Peter John, Royce Koop, Jaime Settle, and James Fowler. 2014. “A Natural Experiment in Proposal Power and Electoral Success.” American Journal of Political Science 58 (1): 189-96.

Louwerse, Tom, and Simon Otjes. 2015. "The Impact of Parliamentary Specialisation on Cosponsorship." Journal of Legislative Studies 21 (4): 476-94.

Lowell, A. Lawrence. 1902. Governments and Parties in Continental Europe. New York: Houghton, Mifflin.

Mayeur, Jean-Marie. 1984. La vie politique sous la Troisième République, 1870-1940. Paris: Pointe Histoire.

Mayhew, David R. 1974. Congress: The Electoral Connection. New Haven, CT: Yale University Press.

Moffett, Kenneth W. 2012. "Parties and Procedural Choice in the House Rules Committee." Congress and the Presidency 39 (1): 1-27.

Monroe, Nathan. 2008. "Do Restrictive Rules Produce Nonmedian Outcomes? A Theory with Evidence from the 101st-108th Congresses." Journal of Politics 70 (1): 217-31.

Olson, David, and Philip Norton. 2007. "Post-Communist and Post-Soviet Parliaments: Divergent Paths from Transition." Lournal of Legislative Studies 13 (1): 164-96.

Padró i Miquel, Gerard, and James M. Snyder. 2006. "Legislative Effectiveness and Legislative Careers." Legislative Studies Quarterly 31 (4): 347-81.

Schiller, Wendy J. 1995. "Senators as Political Entrepreneurs: Using Bill Sponsorship to Shape Legislative Agendas." American Journal of Political Science 39 (1): 186-203.

Schlesinger, Joseph. 1966. Ambition and Politics. Chicago: Rand McNally. Sekhon, Jasjeet, and Rocio Titiunik. 2012. "When Natural Experiments Are Neither Natural nor Experiments.” American Political Science Review 106 (1): 35-57.

Strom, Kaare. 1998. "Parliamentary Committees in European Democracies." Journal of Legislative Studies 4 (1): 21-59.

Usher, Abbott Payton. 1906. "The Reform of Procedure in the French Chamber of Deputies." Political Science Quarterly 21 (3): 475-97.

Wawro, Greg. 2000. Legislative Entrepreneurship in the U.S. House of Representatives. Ann Arbor: University of Michigan Press.

Weingast, Barry R., and William Marshall. 1988. "The Industrial Organization of Congress." Journal of Political Economy 96 (1): 132-63.

Williams, Brian D., and Indridi H. Indridason. 2014. "Luck of the Draw? Members Bills, the Electoral Connection and Party List Placement." Unpublished manuscript, University of West Florida and University of California, Riverside.

Zeldin, Theodore. 1993. The Politicians of the Third Republic. Oxford: Oxford University Press.

Zubek, Radoslaw. 2015. "Coalition Government and Committee Power." West European Politics 38 (5): 1020-41. 